\title{
Tax Incentive Proposals to Enhance Child Support Payment Compliance and Tax Progressivity
}

\author{
Gary M. Fleischman ${ }^{1}$, Zafar Dad Khan ${ }^{2} \&$ Paul D. Hutchison ${ }^{3}$ \\ ${ }^{1}$ School of Accounting, Texas Tech University, Lubbock, TX, USA \\ ${ }^{2}$ Department of Business and Economics, University of Virginia-Wise, Wise, VA, USA \\ ${ }^{3}$ Department of Accounting, University of North Texas, Denton, TX, USA \\ Correspondence: Paul D. Hutchison, Department of Accounting, University of North Texas, Union Circle \#305219, \\ Denton, TX 76203-5017, USA. Tel: 1-940-565-3083. E-mail: paul.hutchison@unt.edu
}

Received: February 10, 2014

Accepted: February 22, $2014 \quad$ Online Published: February 26, 2014

doi:10.5430/afr.v3n2p1

URL: http://dx.doi.org/10.5430/afr.v3n2p1

\begin{abstract}
Currently, $\$ 38$ billion in child support payments is due custodial parents in the United States. The purpose of this study is to investigate the public policy and theoretical economic implications associated with tax incentive proposals for child support payments. Institutional theory and economic modeling theoretically support this investigation. Overall, the study suggests that a tax incentive associated with child support payments would enhance tax progressivity and reduce income inequality while also enhancing non-custodial parent ability to pay their child support legal mandates. A tax incentive may also enhance child support payer perceptions of procedural and retributive justice.
\end{abstract}

Keywords: Child support, Institutional theory, Tax progressivity, Retributive justice

\section{Introduction, Purpose, and Motivation}

In the United States, $\$ 38$ billion in child support payments is due to 6.8 million custodial parents. However, only $\$ 25$ billion was actually received (U.S. Census, 2007). The purpose of this study is to investigate the public policy and theoretical economic implications associated with tax incentive proposals for child support payments that would not only enhance tax progressivity but also reduce income inequality and theoretically increase payer compliance. Non-custodial parents should have a greater ability to pay child support to the custodial parent with a dependent child if he/she can obtain a tax incentive contingent on child support payment compliance. A related theoretical implication of creating a tax incentive for child support payments is it may enhance child support payer perceptions of procedural and retributive justice (Kray \& Lind, 2002; Kirchler, 2007), as well as overall governmental institutional legitimacy, which should enhance payment compliance further (Lin, 2000).

Specifically, this commentary argues for federal tax incentives to boost child support payment compliance based on (1) a public policy argument supported by enhanced institutional legitimacy, fairness, and justice; and (2) a theoretical economic argument. The authors are motivated to conduct this research due to the severe negative societal externalities that currently exist when a non-custodial parent (often the father of a child) does not pay in full his legal obligations for child support, including the problematic economic and psychological impact on the custodial parent (often the mother) and her dependent child(ren). (Note 1) Neither a pro-custodial parent nor pro-non-custodial parent position is taken in this study. Instead, this examination simply seeks to suggest a possible public policy remedy (i.e., tax incentive) that may be beneficial to all parties involved (e.g., father, mother, child(ren), and society as a whole) by increasing the non-custodial parent's ability to pay, while also hopefully enhancing payer perceptions of Internal Revenue Service (IRS) procedural and retributive justice (Kray \& Lind, 2002; Kirchler, 2007).

New York State's recent (2007) announcement that it was creating a child support payment tax credit for non-custodial payers who are current on their support obligations underscores the pragmatic motivation for this research and illustrates that the tax proposals discussed in this study are both realistic and noteworthy from a public policy incentive standpoint (New York State, 2007). Jagannathan (2004, p. 125) probably states the generalized motivation of studying child support payment/collection issues best:

Given what is at stake...our children and, therefore our nation's future... and given what we know about the economic and social consequences of certain types of family living arrangements... it is critical to study the 
factors influencing the living arrangements of children within a comprehensive policy implementation framework.

The authors believe that the study's theoretical development and commentary significantly contributes to the literature regarding the child support payment challenge. Very little academic literature exists in connection with tax-related implications pertaining to child support payments.

The remainder of this research is organized as follows. The next section provides a literature review including Institutional Theory and child support psychology literature that provides context for the study. Then, the modeling of the economics of child support and a review of child support payment tax incentive options is presented. Finally, conclusions are presented.

\section{Literature Review}

\subsection{Background}

In a home where both parents live together with their child, there is generally an automatic sharing of income with the child. When parents live apart, however, this sharing is no longer automatic, so society has established that non-custodial parents, often the father, pay court-ordered child support to ensure pecuniary transfers to the child (Case, Lin, \& McLanahan 2003). Child support transfers in theory are intended to make the two households comparable in terms of standard of living (Folse \& Varela-Alvarez, 2002). In short, when one has a child he/she is under a legal obligation to support that child until they are 18 years of age; thus, many people assert that child support is a right of the child (e.g., Sasser, 1999).

During the past four decades, single-parent households have become more of the norm than the exception, and it is estimated that over half of today's children are expected to live apart from at least one biological parent before they are 18 years old (Bumpass \& Lee, 2000). Children in single-parent families generally suffer numerous psychological, social, and economic disadvantages, as compared to children in families containing both biological parents (Jagannathan, 2004). However, increased child support payments have been found to not only help children economically, but also is associated with enhancing their academic achievement (Knox, 1996). Therefore, the use of "child support has become an increasingly important policy instrument for reducing economic insecurity among single mothers and their children" (Case et al., 2003, p. 171).

\subsection{Institutional Theory - The Governmental Public Policy Perspective}

Institutional Theory (Meyer \& Rowan, 1977; DiMaggio \& Powell, 1983) provides public policy theoretical support for this study and explains why the government should be motivated to revise the public policy on child support payments so that payer perceptions of justice and fairness are enhanced. This theory allows accounting research to assess institutional actions that, by necessity, involve both power and politics (Covaleski \& Dirsmith, 1991), and thus, is appropriate for research that involves the United States (U.S.) government. A few noteworthy accounting studies have employed Institutional Theory in the past, and they provide excellent reviews of the relevant literature in conjunction with accounting context public policy issues (e.g., Covaleski \& Dirsmith, 1991; Fogarty, 1992; Carruthers, 1995; Carpenter \& Feroz, 2001).

In sum, Institutional Theory promulgates that organizations (including the U.S. Congress (Congress) and Treasury Department's Internal Revenue Service (IRS)) must conform to external institutional pressures because this behavior enhances societal perceptions of the organization's credibility and legitimacy, which correspondingly promotes access to resources as well as organizational survival (Meyer \& Rowan, 1977; DiMaggio \& Powell, 1983; Fogarty, 1992). Public sector organizations, such as the government in general, and Congress and the Treasury Department in particular, must be sensitive to societal opinions and perceptions regarding legal processes and fairness, since ultimately these viewpoints are more important to these entities' survival and success than actual organizational functioning (Meyer, 1986; Covaleski \& Dirsmith, 1991). Therefore, Congress is concerned that the laws they create and reform are consistent with societal norms of equity, so that they positively influence citizen perceptions and attitudes about process fairness (e.g., Lin, 2000; van den Bos, 2002; Fleischman et al., 2007), as well as procedural and retributive justice (Kray \& Lind, 2002; Kirchler, 2007). This is especially important in the context of the current societal conundrum pertaining to child support payment compliance. If child support payers do not believe that the legal system governing support payments is fair, they are less likely to comply with system mandates because they perceive that this governmental public policy lacks societal legitimacy and fairness.

Institutional Theory therefore contends that it is essential for public sector organizations to establish societal legitimacy with the citizenry. To do this, they must implement comparable practices to other organizations so that over time they start to look and behave similarly regarding politics and "ceremony" (DiMaggio \& Powell, 1983, p. 150). 
This metamorphosis towards organizational homogeneity is termed "institutional isomorphism" and can be classified as mimetic, normative, and coercive isomorphism (DiMaggio \& Powell 1983, p. 150). Each of these classifications will be briefly defined below.

Mimetic isomorphism occurs when organizations respond to institutional pressures that encourage similar responses to the particular environment faced by the organizational association (DiMaggio \& Powell, 1983; Fogarty, 1992). For example, one would expect that the legal adjudication associated with child support payment compliance cases would be applied using fair and equitable due process of law procedures in accordance with the Personal Responsibility and Work Opportunity Reconciliation Act of 1996 (PEWORA, 1996), as should be the case with any other legal process, whether it involves criminal, civil, or tax law.

Normative isomorphism refers to institutional pressures that emanate from societal norms of justice and equity (DiMaggio \& Powell, 1983). For example, it is clear that non-custodial fathers do not generally perceive that the current child support payment process is fair and just. There is considerable lobbying and public outcry by these fathers to reform the law to make it more fair and equitable from their standpoint and to enhance their ability to pay their legal child support obligations. Similarly, there is an equal or even greater societal outcry from custodial mothers who bemoan the fact that they and their dependent children must face economic hardships because the custodial fathers do not faithfully pay legally mandated child support payments. In short, these normative pressures from both sides of the child support payment challenge place pressure on Congress to reform the law in order to meet these societal demands. The present study proposes that a tax incentive for child support payments would likely represent a concrete and ideological positive step towards addressing these societal concerns of both the custodial mother and the non-custodial father.

Finally, DiMaggio \& Powell (1983) describe coercive isomorphism that emanates from formal constituent organizations (such as Congress and the Treasury Department in the present study), as well as informal constituent groups. For example, Congress is responsible for establishing the laws in the United States and must reform the laws as they did with PEWORA in 1996 when it becomes clear that existing law does not meet societal norms for equity, fairness, and effectiveness. The present study urges Congress to consider a tax incentive for child support payments in order to meet the societal demands of both custodial mothers and non-custodial fathers. Figure 1 depicts the roles of all three forms of isomorphism as they pertain to the present study regarding public policy of child support payments.

\subsection{Child Support Psychology Literature}

The child support psychology literature seems to suggest that in the aggregate the government has lost institutional legitimacy among most payers of child support. This is a crucial conclusion, because it partially explains why child support payment compliance is still a deeply troubling public policy issue in the United States. Based on the above discussion of Institutional Theory, the government now has the burden of shifting its child support compliance strategy in order to reclaim the respect and legitimacy of non-custodial fathers. The child support payment legal process must undergo a transformation in order for payers of child support to view it as fair and just, and only when the process regains its respect and legitimacy can one expect non-custodial payers to voluntarily comply with legally-mandated payments.

Procedural justice and retributive justice are both relevant to child support payment compliance public policy issues and are associated with normative isomorphism (see Figure 1). Procedural justice exists in the present study when persons who are required by law to pay child support believe that the process that generated the payment mandate was fair and equitable (Kirchler, 2007). Retributive justice, on the other hand, is "concerned with the perceived appropriateness of sanctions" (Kirchler, 2007, p. 76) in association with the application of law (i.e., mimetic isomorphism, see Figure 1). In the present study, this may refer to how appropriate non-custodial fathers perceive their support payment mandate to be. If they perceive that it exceeds their ability to pay, their perception of retributive justice will be poor. Similarly, if the non-custodial father falls behind on his child support payments, and he is subsequently jailed or subject to onerous civil or criminal penalties, this too will seriously damage perceptions of retributive justice. 


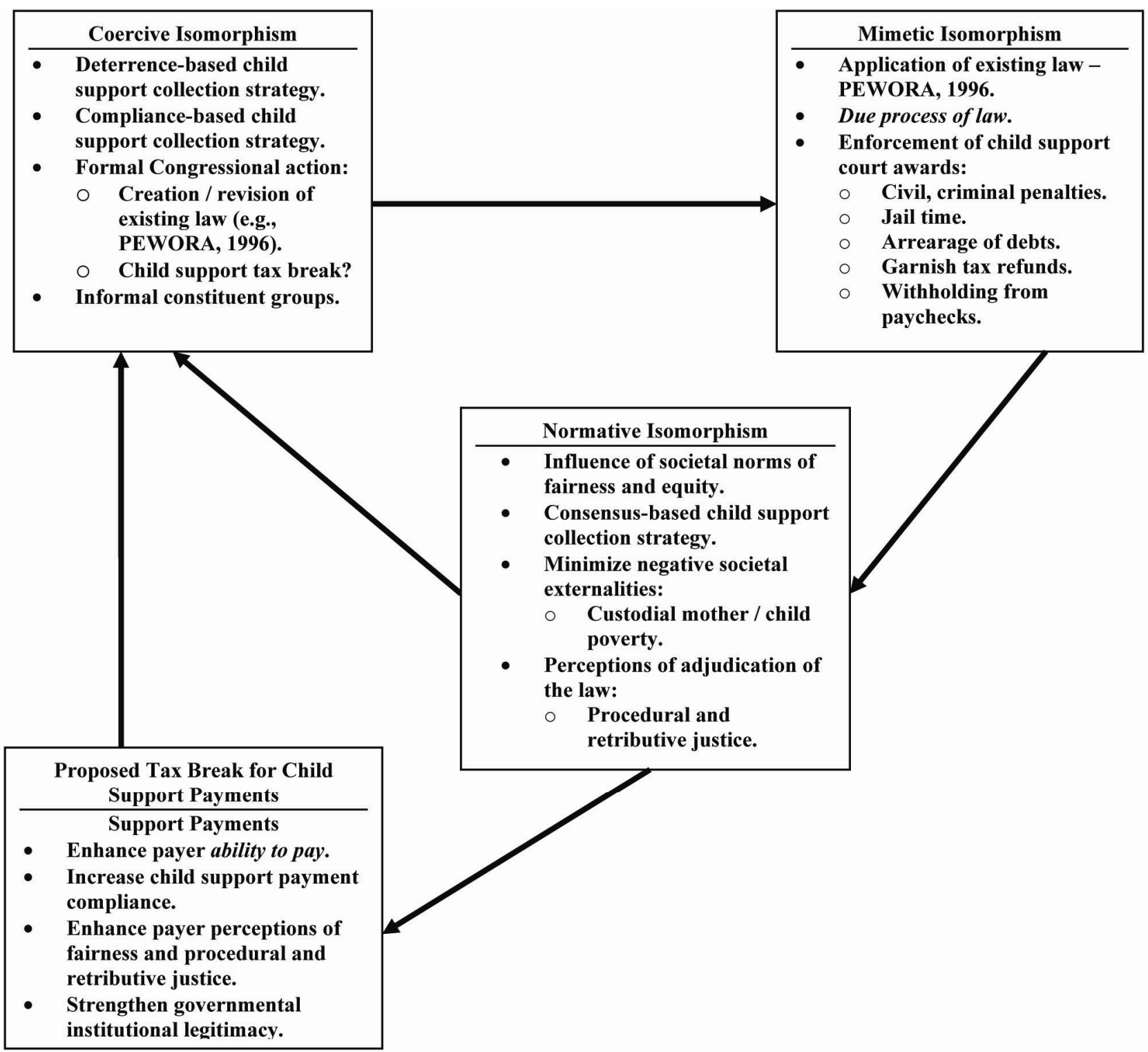

Figure 1. Interaction of Institutional Theory and Public Policy of Child Support Payments

(Adapted from DiMaggio \& Powell, 1983; Fleischman et al., 2007 and 2009).

\subsection{Severity of Noncompliance and the 1996 Legislation Overhaul}

Because child support is such an important source of income for single mothers and their children, there is considerable societal anxiety about the social injustice caused by poverty and deprivation of mothers and children who do not receive their legally-mandated payments. Based on the most recent information, approximately 23 percent (about 1.6 million custodial parents) received no child support at all, which translates to about $\$ 13.2$ billion of uncollected support in 2005 (U.S. Census Report, 2007). A less recent but possibly idealistic report suggested that non-custodial fathers could pay $\$ 34$ billion more in child support if they all had support orders and these orders were fully paid (Sorensen 1997), which further exacerbates the public uproar over this contentious issue. Consequently, during the past 20 years public policy has attempted to both target and streamline all stages of the child support process, including 1) paternity establishment, 2) legal (formal) support orders, and 3) enforcement of those orders in order to maximize the payment of child support by non-custodial fathers (Bartfeld, 2003). In fact, PEWORA of 1996 (Public Law 104-193) substantially replaced the child support process that had been in existence for 60 years with a new program designed to strengthen the child support enforcement system (Cancian \& Meyer, 2004). 


\subsection{Approaches to Enhance Compliance}

Lin (2000, p. 389) developed a theoretical framework regarding three potential pragmatic approaches to ensuring public compliance with child support payment mandates:

1) Deterrence-based approach. Using this paternalistic public policy approach, society identifies actual child support non-payers to assess them with civil or criminal charges. This may involve jailing the person in the most severe cases, possibly intercepting tax refunds, or putting liens on the offender's property. The literature suggests that there is some evidence that these policies increase overall child support collections (Sorensen \& Halpern, 1999). Some public policy attempts during the post-1996 reforms to browbeat so-called "deadbeat dads" into paying child support have had disastrous effects, however. For example, putting delinquent payers in prison not only bogged down the penal system, but also severely hurt their chances of obtaining gainful employment once they got out of jail with severe arrearage of debts (Byrd, 2000). This approach is a form of coercive isomorphism and application of this approach represents mimetic isomorphism (see Figure 1).

2) Compliance-based approach. This pre-emptive policy strategy creates standards and then uses enforcement to oversee compliance behaviors before the law is broken. Examples of this strategy include automatically withholding child support payments from paychecks. Research generally supports that this withholding technique has a positive association with child support payment compliance (e.g., Garfinkel \& Robins, 1994; Sorensen \& Halpern, 1999). This approach is again a form of coercive isomorphism and its application is a form of mimetic isomorphism (see Figure 1).

3) Consensus-based approach. This approach assumes that society will comply with the law because their personal norms for behavior coincide with the norms defined by the law (Horwitz, 1990) and not because they fear punishment (deterrence-based approach) or because their behavior is regulated (compliance-based approach). This approach promulgates that there are two ways to change social norms: one can either widely enforce a new law so that citizens change their behavior, or one may use different media to persuade the citizenry of the merits of the new law by changing their attitudes (Lin, 2000). One study asserts that if non-custodial fathers perceive that the child support process treats them fairly, they will be more likely to comply with their child support orders (Lin, 2000). This approach appeals to societal norms of equity, and therefore, represents normative isomorphism (see Figure 1). This approach is likely most effective and would also enhance the government's institutional legitimacy as espoused by Institutional Theory (e.g., Meyer \& Rowan, 1977; DiMaggio \& Powell, 1983).

A tax incentive for child support payments may be an effective means to positively influence payer perceptions and attitudes about process fairness (e.g., Lin, 2000; van den Bos, 2002; Fleischman et al., 2007), as well as procedural and retributive justice (Kray \& Lind, 2002; Kirchler, 2007) associated with the overall child support payment system in general. Such a tax incentive may be viewed as societal support and understanding of the ability to pay hardships that lower- and middle-income payers experience on a monthly basis and should enhance governmental (in general) and IRS (in particular) institutional legitimacy (Meyer \& Rowan, 1977; DiMaggio \& Powell, 1983).

\subsection{Barriers to Compliance}

The term "deadbeat dad" has been coined to refer to non-custodial fathers who selfishly do not pay their legal child support obligations even though they have the economic ability to do so (Christensen, 2001). Although no doubt many such persons exist, contemporary research in this area has been focusing on why non-custodial fathers do not pay, or do not pay all their legally mandated child support obligations. Specifically, the literature has identified at least four major barriers that limit a non-custodial parent's ability to pay child support:

1. "(L)imited connection to the labor force;

2. Low and fluctuating earnings that make it difficult to comply with support orders;

3. Support orders that do not reflect current earnings; and

4. The accumulation of (debt) arrearages that many fathers have little hope of paying" (Cancian \& Meyer, 2004, p. 183).

In short, many child support non-payment issues do pertain, either directly or indirectly, to a non-custodial father's ability to pay (Sorensen, 1997; Bartfeld, 2003; Case et al., 2003; Cancian \& Meyer, 2004). One study notes that fathers of children born outside marriage have even less incentive to pay child support because a large proportion of their children are members of a family on welfare, meaning that the children can only receive at most $\$ 50$ of their father's child support payment per month (Case et al. 2003). Furthermore, women's earnings increased dramatically during the 1970s and 1980s, while the earnings of men with less than a college education declined (Case et al., 2003). Paying 
child support causes few fathers to fall below the poverty line, but child support payment obligations of low income fathers tend to be a higher percentage of income as compared with fathers with moderate or high income levels (Cancian \& Meyer, 2004). Generally, the preponderance of research evidence suggests that fathers with the least income are also least likely to pay their child support obligations, and many fathers are so burdened by debt arrearages that they do not believe they will ever be able to pay these substantial debts (Cancian \& Meyer, 2004).

\subsection{Ability to Pay: Theoretical Development and Economics of Child Support}

A basic assumption underlying the following framework is that both mother and father value their child's welfare, meaning that each therefore benefits from the other's actions taken to increase this welfare. In a united two parent family, physical proximity generally acts to maximize both parents' investment in their children so that each parent individually enjoys the incremental investment to a child's welfare made by the other parent along with his/her own investments for the child (Beller \& Graham, 1985, 1986; Weiss \& Willis, 1985; Teachman, 1991).

This mutual welfare investment synergy breaks down, however, after the parents divorce or separate, because now the father loses his control over the goods and services allocated for his child's welfare versus those consumed by the child's mother. Additionally, the father's beneficial utility from his enjoyment of his children is substantially diminished because of increased physical distance (Beller \& Graham, 1985, 1986; Weiss \& Willis, 1985; Teachman, 1991).

The extent of resource transfers from the non-custodial father to his children is based on negotiations between father and mother, given legal constraints, with each ex-spouse trying to maximize personal preferences, subject to the constraint of concern for their child's welfare. The negotiation outcome is the time outlay and material support pledged by the father (Beller \& Graham, 1985, 1986; Weiss \& Willis, 1985; Teachman, 1991).

The economics of child support payments gained importance due to the decline in the proportion of married-couple families during the last few decades. This is important because in this study it is assumed that single-parent families most often headed by a mother have less household income than a comparable married-couple family with children. The U.S. Census data (2008, Table 1) supports this assumption, given that the median income of married-couple family households in 2007 was $\$ 72,785$. In contrast, the 2007 median income of a male-headed single parent households was $\$ 49,839$ and the median income of a female-headed single parent households was $\$ 33,370$.

In this discussion and modeling, the study does not develop a new theoretical model but instead discusses how this study incorporates a tax incentive for child support payments that is best described by augmenting existing economic models of child support (e.g., Weiss \& Willis, 1985; Beller \& Graham, 1986; Boca \& Flinn, 1995; Flinn, 2000). The focus will be only on divorced parents who are not acting cooperatively, which is consistent with the social conundrum involving sporadic child support payments.

The previously mentioned child support models assume that utility (welfare) functions of the parents are dependent on both their own and their child's consumption. The utility functions in these models are also jointly determined because there remains a common good of interest, the child. Here, let $u_{p}$ represent a parent's utility (custodial, $c$ or non-custodial, $n c)$ and $e_{p}$ represent expenditures on themselves. $I$ is the investment on the child. Therefore, total parental income is given as: $Y_{T}=Y_{c}+Y_{n c}=e_{c}+e_{n c}+I$ (income $=$ expenditure). In addition, if we assume that one spends $\alpha$ percent of her total income on herself and $(1-\alpha)$ percent on the child, then the utility function of a parent mother $p$, is presented as:

$$
\begin{aligned}
& u_{p}\left(e_{p}, I\right)=\propto_{p} \ln \left(e_{p}\right)+\left(1-\propto_{p}\right) \ln (I) \\
& \text { where, } \propto_{p} \in[0,1] \text { and } \in[\mathrm{c}, \mathrm{nc}]
\end{aligned}
$$

The allocation of wealth of a divorced couple depends on who has the custody of the child and therefore, also controls the child's expenditures. The allocation of wealth under divorce is also pareto inefficient compared to a married-couple, since the custodian parent (usually mother) chooses $\alpha$ without considering the effects on the father (Weiss \& Willis, 1985). In a divorce state, however, the ex-wife custodial parent may maximize her utility given the ex-husband's parallel independence and satisfaction level that implies that it is rational to give up the child custody while otherwise making support payments to maximize the child's welfare. Otherwise, the child may experience low levels of expenditure. The non-custodial father's relative trade-off of custody versus support may also be driven by a certain degree of altruism corresponding to higher levels of income transfer to his child. Indeed, the "collective good hypothesis" explains why transfer of custody rights and support payments normally travel in the same direction (Weiss \& Willis, 1985). 
The static solution of the problem is unique (Boca \& Flinn, 1995; Flinn, 2000). Given her total income $\left(Y_{C}+t_{N C}\right)$, the investment/expenditure $(I)$ by the mother $(c)$ on the child and the optimal transfer $(t)$ from the father $(n c)$ are given by the following equations:

$$
\begin{gathered}
I^{*}\left(Y_{C}, t_{N C}\right)=\left(1-\propto_{C}\right)\left(Y_{C}+t_{N C}\right) \\
t^{*}\left(\propto_{C}, Y_{T}\right)=\left\{\begin{array}{ll}
\left(Y_{N C}-\propto_{N C} Y_{T}\right) & \text { if } \propto_{N C}<\frac{Y_{N C}}{Y_{T}} \\
0 & \text { if } \propto_{N C} \geq \frac{Y_{N C}}{Y_{T}}
\end{array} \text { where, } Y_{T}=Y_{C}+Y_{N C}\right.
\end{gathered}
$$

These values determine the maximum utility for both the parents given the usual state of non-cooperation. One should note that the amount of child-support order $(s)$ does not appear anywhere in this optimization problem and therefore, conclude nothing about the compliance behavior. Therefore, a slightly modified utility function was proposed by Boca \& Flinn (1995):

$$
u_{p}\left(e_{p}, I\right)=\propto_{p} \ln \left(e_{p}\right)+\left(1-\propto_{p}\right) \ln (I)-v I[t<s]
$$

The new term on the right hand side represents an overall disutility due to a lack of child support compliance. The father with the utility function in (4), over-complies when $\propto_{N C}$ is low or when the voluntary transfer $(t)$ exceeds the value of child $\operatorname{support}(s)$ or when $\propto_{N C} \leq \frac{\left(Y_{N C}-s\right)}{Y_{T}}$. Partial-compliance (where $\left.t<s\right)$ takes place when $\propto_{N C} \in\left\{\frac{\left(Y_{N C}-s\right)}{Y_{T}}\right.$, $\left.\frac{Y_{N C}}{Y_{T}}\right\}$. The non-custodial parent doesn't transfer anything if $\propto_{N C} \in\left\{\frac{Y_{N C}}{Y_{T}}, 1\right\}$.

As previously mentioned in the literature review, the percentage of partial or no child support compliance is fairly high among divorced ex-husbands with a dependent child. Therefore, the question regarding compliance remains open: What tax incentive mechanism should be designed to increase payment compliance?

The study now wishes to analyze if the proposed policy of child support payment deductibility makes theoretical sense to increase child support transfers and therefore, compliance. The dilemma, however, faced by a father is whether to transfer the child support or not and if yes, then how much. The reason for this dilemma is the mother's ability to control the support money while the father remains uncertain about the proportion of the resources spent on the benefit of the child. Policymakers may achieve a pareto improvement with (1) a conditional child support transfer, or (2) a tax-incentive for the child support.

To illustrate this first strategy, the father can try to achieve pareto improvement in a divorce state by internalizing the interest of the mother and making the child support transfer conditional that she spend these monies specifically on the child (Weiss \& Willis, 1985). However, the incentive of higher transfer, coupled with greater child expenditures may or may not work, since the monitoring cost of observing those expenditures is too high for the father, and it may be difficult for the mother to effectively signal her actions to influence the father's support outlays. Furthermore, if the mother transfers a greater percent of child support payments specifically for the child, this in turn may create suboptimal behavior by inducing the father to subsequently consume more personally and thus, ultimately reduce child support payments in the last analysis (Beller \& Graham, 1986). In a related vein, a decrease in the mother's own consumption levels $\left(\alpha_{C}>\alpha_{C}{ }_{C}\right)$ means the proportion spent on the child's expenditure is higher, which is now $\left(1-\alpha^{\prime}\right)$. This influences the budget line (see Figure 2) to move to the right $\left(A^{\prime} B^{\prime}\right)$, and it also becomes steeper as a result (the new slope, $-\left(1-\alpha^{\prime} C\right)$ is higher). The impact on the father is theoretically ambiguous, since he may pay more or lesser amounts of child support depending on his preference pattern and altruism for his child, as well as the magnitude of the increase in proportion to expenditures directed to the child. The upward shift in the budget line increases both the consumption for the father and the child, but the higher slope induces the father to pay lesser amounts of child support (Beller \& Graham, 1986). Therefore, the total effect on child support transfer remains ambiguous. 


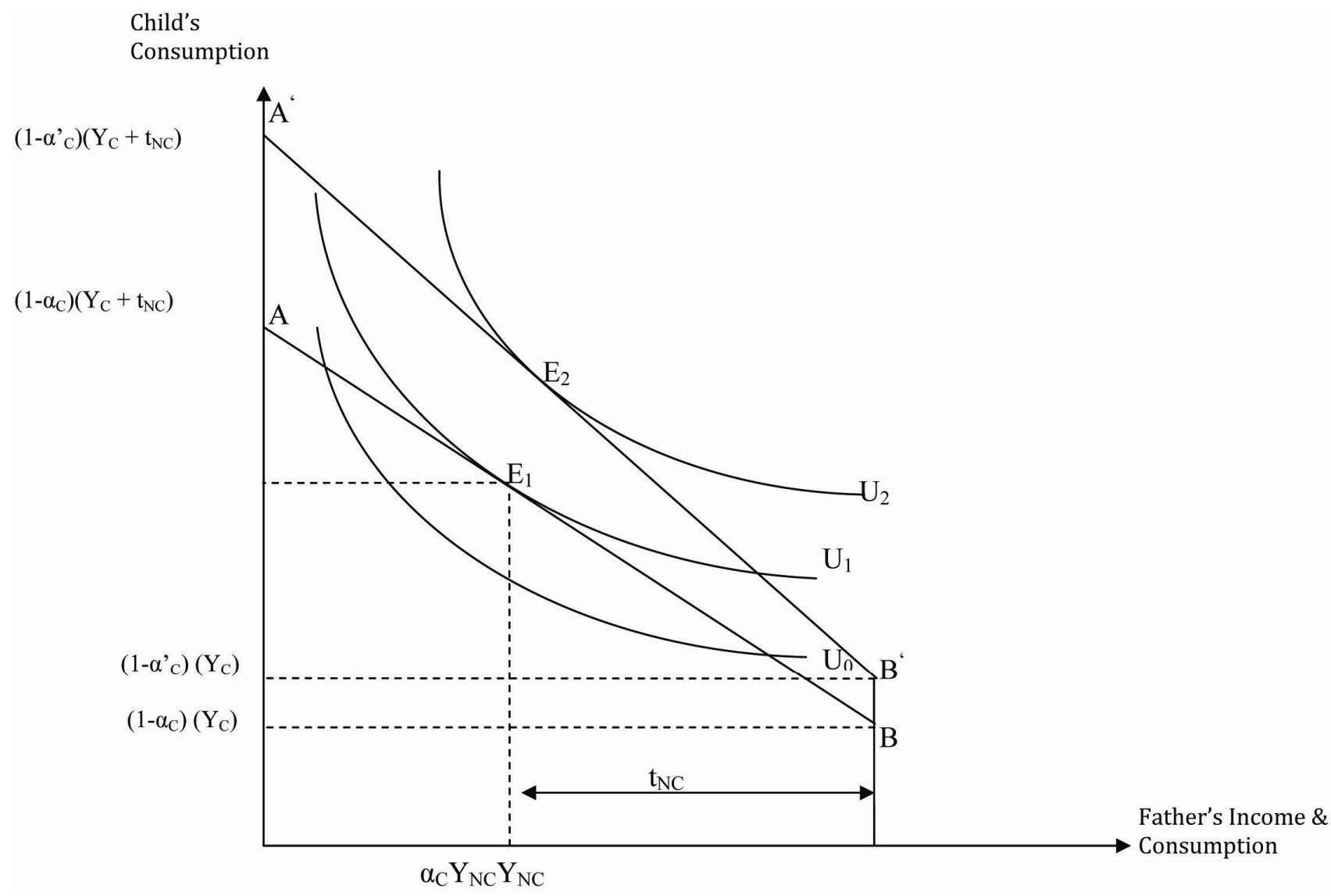

Figure 2. Mandated increase in mother's proportional expenditure on the child may or may not ultimately increase child support transfers.

To illustrate the second strategy, a tax-incentive for the father's child support payments is another option that raises the disposable income of the father $\left(Y_{N C}\right)$ and therefore, increases the probability of satisfying the compliance-conditions: $\left(\frac{Y_{N C}}{Y_{T}}>\propto_{N C}>\frac{\left(Y_{N C}-s\right)}{Y_{T}}\right.$ or $\left.\propto_{N C} \leq \frac{\left(Y_{N C}-s\right)}{Y_{T}}\right)$. This leads to higher investment (payments) to his child as illustrated by Figure 3. The child's consumption on the $y$-axis and the father's income and consumption on the $x$-axis are also measured. The transfer is given by $t$ which is the remaining income after the father's personal consumption. The child's consumption is measured as the percentage of the mother's total income, $\left(Y_{C}+t_{N C}\right)$ which she doesn't spend on her own consumption. The utility functions of the father are represented by $U_{0}, U_{1}$, and $U_{2}$ curves that also show diminishing marginal rate of substitution between the child's consumption and the father's consumption. A steeper utility or indifference curve will imply a lesser preference for the child's consumption. The budget lines are represented by $A B$ or $A^{\prime} B^{\prime}$ for the non-custodial father's income $Y_{N C}$ or $Y_{N C}^{\prime}$ respectively. At $A$, he transfers all income in the form of child support to the custodial mother and child, while at $B$, he transfers nothing to them. The slope of the budget line is $-\left(1-\propto_{C}\right)$ which implies that if one reduces his consumption by $\$ 1$, it will raise the child's consumption by $\$\left(1-\propto_{C}\right)$.

The initial equilibrium is represented by $E_{l}$ where the father maximizes his satisfaction and the indifference curve, $U_{l}$, is tangent with the budget line representing no incentive for the father to trade-off anymore. At this point, he keeps, $\$ \alpha_{C} Y_{N C}$ for his own consumption by transferring the rest as child support, $\$ t_{N C}$. A proposed tax incentive maximizes his own satisfaction on the indifference curve, $U_{2}$. This increases his transfer in child support from to. His own consumption also increases to $\alpha_{C} Y_{N C}^{\prime}$. The father is therefore most likely (holding constant the normal set of assumptions of consumer behavior) going to increase his own consumption by using some of his additional income 
(due to increased ability to pay) personally while the rest is likely to be spent on his child (Beller \& Graham, 1986). The theory, therefore, explains that the tax incentive for child support payments that enhances a father's ability to pay should help the custodial mother and dependent child if the assumptions of utility theory hold.

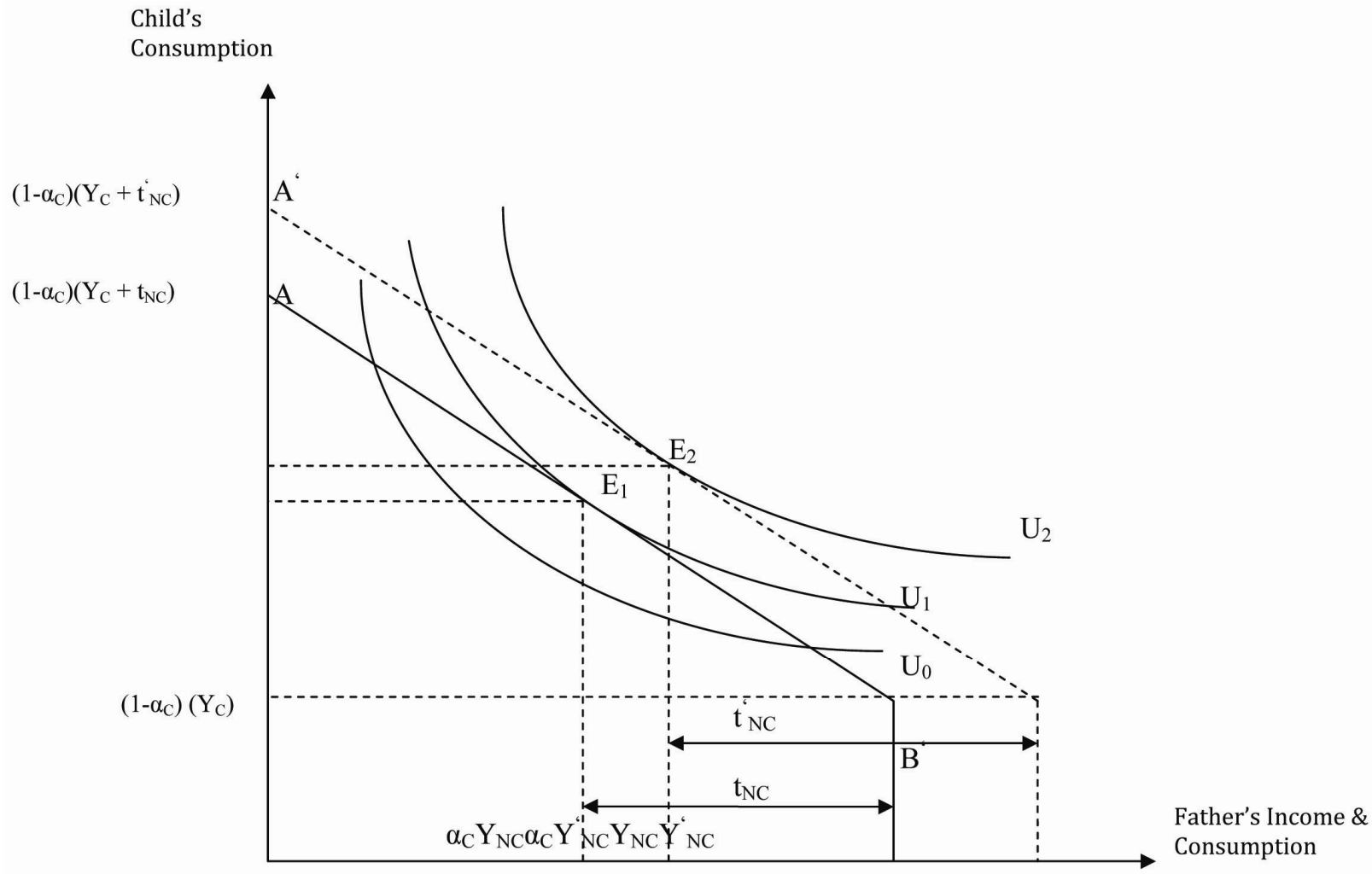

Figure 3. The Tax Incentive for Child Support: Increase Ability to Pay.

\subsection{Ability to Pay Enhanced by a Tax Incentive-But What Kind?}

Because the ability to pay issue is significantly linked in the literature to compliance (e.g., Bartfeld \& Meyer, 2003), some researchers have suggested public policy changes that would help the non-custodial parent satisfy his child support obligations (Curran, 2003). Curran (2003) suggests that Congress create a tax credit to help with the ability to pay conundrum. Folse and Varela-Alvarez (2002) concur, mentioning that currently no tax benefits are associated with child support payments, while the receipt of child support income is non-taxable. They also argue a lack of relative tax equity for non-custodial parents, given that the custodial parent may claim dependency exemptions, head of household status, as well as the child tax credit for children under 17 (Folse and Varela-Alvarez, 2002).

Two articles have appeared in the professional accounting literature that promote a tax benefit of some kind to enhance non-custodial father ability to pay issues. Hutchison \& Fleischman (2001) suggested that Congress provide some kind of tax incentive, most likely a deduction "for" adjusted gross income (AGI) or a tax credit, to encourage non-custodial fathers to pay their child support obligations. In a more recent follow-up article, Hutchison, Fleischman, and Anders (2007) suggested a deduction "for" AGI or a tax credit for child support payments to not only encourage compliance but to also increase payer perceptions of system fairness based on Lin's (2000) consensus-based approach to public policy that should also bolster governmental institutional legitimacy. Hutchison et al. (2007, p. 41) note that "(f)athers' advocacy groups often cite a lack of fairness in the legal process as a key reason why non-custodial fathers do not pay child support, which suggests a lack of institutional legitimacy. Hutchison et al., (2007) also noted that a tax incentive for child support payers would increase the taxation equity with custodial parents, thus addressing the Folse and Varela-Alvarez (2002) argument above. In summary, Hutchison et al. (2007, p. 42) conclude the following:

A tax incentive for child support payments would produce a win/win/win/win situation:

1) Noncustodial parents would be encouraged to make child support payments because the tax incentive would reduce the after-tax-cost of such payments while also enhancing payer perceptions of societal fairness;

2) Custodial parents would receive support payments to decrease household financial insecurity; 
3) Children would benefit from funds received by the custodial parent for their welfare, thus decreasing poverty; and

4) The time and money spent by society and the legal system in enforcing and collecting child support (e.g., courts, attorneys, incarceration costs, collectors, etc.) would decrease.

The authors also suggest that any tax incentive that Congress would consider should have a phase-out provision to target benefits to middle- and lower-income taxpayers (Hutchison et al., 2007), which is the group Congress has historically attempted to benefit (U.S. Congress, Joint Committee, 1981).

A February 5, 2007 on-line article located on the New York State Office of Temporary and Disability Assistance website (NYS OTDA, 2007) reports that New York State is the first state in the United States to provide non-custodial parents with a tax incentive. The tax benefit is a refundable tax credit that is available to non-custodial parents who make their child support payments on time, which will enhance their ability to pay child support in the future (NYS OTDA, 2007). To qualify for the credit, non-custodial parents must be at least 18 years old, have a child who does not live with them, and have a New York State child support order that the non-custodial parent is making current up-to-date payments on.

\subsection{Overcoming Barriers}

Based on the above literature and theory, a key barrier that non-custodial fathers face regarding paying child support obligations in full is their limited ability to pay such obligations (e.g., Bartfeld \& Meyer, 2003). The thesis of this exploratory public policy study is that a federal tax incentive would increase the after-tax income of non-custodial parents, thus enhancing their ability to pay child support, which should increase compliance and fairness perceptions. Ideally, it is asserted that a child support payment tax incentive that would increase the ability to pay could also be viewed as a consensus-based approach to compliance based on Lin's (2000) arguments, since this may be an effective means to transform the attitudes of the citizenry regarding the overall fairness (van den Bos, 2002; Fleischman et al., 2007) and justice (Kray \& Lind, 2002; Kirchler, 2007) of the child support payment process. Institutional Theory (Meyer \& Rowan, 1977; DiMaggio \& Powell, 1983) suggests that strengthened child support payer fairness and justice perceptions associated with the child support payment process should also enhance perceptions of governmental legitimacy, which should theoretically further bolster payment compliance.

\subsection{Design Options for the Proposed Child Support Payment Tax Benefit}

Because there currently is no Federal tax incentive for child support payments, any proposals that could be suggested is by definition arbitrary. With this fact in mind, however, the authors wish to propose two alternative tax breaks that would be potentially feasible based on tax deductions and credits that currently exist in the Internal Revenue Code. The suggested tax breaks in this paper are designed to target middle- and lower-income taxpayer groups, and thus, enhance tax progressivity (Seetharaman, 1994; Seetharaman \& Iyer, 1995; Dunbar, 1996; Iyer \& Seetharaman, 1997; Young, Nutter, \& Wilkie, 1999), so both alternatives presented contain phase-outs to accomplish this purpose.

The most logical child support tax benefit design alternatives were: 1) a deduction "from" AGI (itemized deduction), 2) a deduction "for" AGI, and 3) a tax credit. This study concurs with Hutchison et al. (2007, p. 42) that a deduction "from" AGI (itemized deduction) is not a feasible alternative because only about $33 \%$ (based on 2003 Statistics of Income data) itemize, and 80 percent of itemizers have AGIs of over $\$ 50,000$. "Thus, an itemized deduction for child support payments would likely only assist wealthier taxpayers who itemize, and who are more likely to meet their support obligations ..." (Hutchison et al., 2007, p. 42). Therefore, two tax incentives were developed for child support payments, a deduction "for" AGI and a tax credit.

1. Deduction "for" AGI option. When designing this form of child support deduction, a review was made of the existing list of deductions "for" AGI to determine which specific deduction would be most appropriate to use as a model. Alimony payments are completely deductible, but it was not thought that this would be appropriate for consideration based on progressivity and tax expenditure concerns. After considerable review and discussion, it was agreed that a design that is consistent with the tuition and fees deduction be selected, which purposes to target similar taxpayer income groups. Therefore this study proposed a deduction "for" AGI equal to a maximum of $\$ 4,000$, limited by the amount of actual child support payments. Likewise, an AGI phase-out is incorporated for single and head of household taxpayers with AGIs of $\$ 65,000$ to $\$ 80,000$ and for married filing joint taxpayers between $\$ 130,000$ and $\$ 160,000$ as mandated by the tuition and fees deduction.

2. Tax credit option. A similar procedure was used to identify an existing tax credit that could be used to model a proposed credit for this study that focuses on both low- and middle-income taxpayers. This income-level focus is consistent with the groups of taxpayers that Congress deems are most in need of tax relief (U. S. Congress, Joint 
Committee, 1981), and continues to be the focus today. After considerable deliberation, it was decided to model a proposed credit after the child and dependent care credit. After reviewing the purpose and congressional intent associated with this credit, it was concluded that it was ideologically similar to what a proposed child support credit should be.

Therefore, the child and dependent care credit limits for the 2001 tax year (the year of this study) were used as a guide for the present study. The maximum 2001 credit is 30 percent of up to $\$ 2,400$ of qualifying child support costs associated with one child, or $\$ 720$. This maximum credit doubles to 30 percent of up to $\$ 4,800$ of qualifying costs (credit equals $\$ 1,440$ ) for two or more children. The maximum allowed percentage is reduced from 30 percent as adjusted gross income increases, to a base of 20 percent for adjusted gross incomes of $\$ 28,000$ or more.

\section{Conclusions}

Since both child support payment tax incentive options would increase payer ability to pay, Institutional Theory advocates that such a tax incentive would also likely enhance payer perceptions of IRS institutional legitimacy, as well as procedural and retributive justice, consistent with Kray \& Lind (2002) and Kirchler (2007). Strengthened child support payer fairness and justice perceptions combined with an increased ability to pay should theoretically increase payer compliance.

Although the tax incentive proposals that are suggested in this study generally constitute tax expenditures, it should be remembered that this public policy strategy likely would also provide cost savings if Institutional Theory is an accurate predictor and child support payers subsequently increase their compliance behavior. For example, time and pecuniary outlays that society in general and the legal system in particular currently expend to enforce child support payment compliance may be diminished, including costs associated with court deliberations, attorney fees, collection efforts, as well as incarceration costs (Hutchison et al., 2007).

Given that the Obama administration seems to favor tax credits as part of tax reform, policymakers may favor the credit option. In order to ensure that lower income child support payers actually receive a tax benefit from the credit, it may be wise to structure the credit as a refundable credit, as opposed to a non-refundable credit.

\section{References}

Bartfeld, J. (2003). Falling Through the Cracks: Gaps in Child Support Among Welfare Recipients. Journal of Marriage and the Family 65(1), 72-89. http://dx.doi.org/10.1111/j.1741-3737.2003.00072.x

Bartfeld , J., \& D. Meyer. (2003). Child Support Compliance Among Discretionary and Nondiscretionary Obligors. Social Service Review 77(3), 347-372. http://dx.doi.org/10.1086/375793

Beller, A., \& J. Graham. (1985). Variations in the Economic Well-being of Divorced Women and Their Children, in M. David and T. Smeeding (Eds.) Horizontal Equity, Uncertainty, and Economic Well-Being. Studies in Income and Wealth Series 50: 471 - 506, National Bureau of Economic Research. Chicago. IL: University of Chicago Press. http://dx.doi.org/10.7208/chicago/9780226137285.001.0001

Beller, A., \& J. Graham. (1986). The Determinants of Child Support Income. Social Science Quarterly 48, 353-364.

Boca, D., \& C.J. Flinn. (1995). Rationalizing Child Support Decisions. American Economic Review 85, 1241-1262.

Bumpass, L., \& H.H. Lee. (2000). Trends in Cohabitation and Implications for Children's Family Context in the U.S. Population Studies, 54(1), 29-41. http://dx.doi.org/10.1080/713779060

Byrd, D. (2000). Making Dad Matter. National Journal, 32, 1196-1208.

Cancian, M., \& D. Meyer. (2004). Fathers of Children Receiving Welfare: Can they Provide More Child Support? Social Service Review, 78(2), 179-206. http://dx.doi.org/10.1086/382766

Carpenter, V.L., \& E.H. Feroz. (2001). Institutional Theory and Accounting Rule Choice: An Analysis of Four US State Governments' Decisions to Adopt Generally Accepted Accounting Principles. Accounting, Organizations and Society, 26, 565-596.

Carruthers, B.G. (1995). Accounting, Ambiguity, and the New Institutionalism. Accounting, Organizations and Society, 20(4), 313-328. http://dx.doi.org/10.1016/0361-3682(95)96795-6

Case, A.C., I.F. Lin, \& S. McLanahan. (2003). Explaining Trends in Child Support: Economic, Demographic, and Policy Effects. Demography, 40 (1), 171-189. http://dx.doi.org/10.1353/dem.2003.0002

Christensen, B. (2001). The Strange Politics of Child Support. Society, 39(1), 63-71. http://dx.doi.org/10.1007/BF02712621 
Covaleski, M.A., \& M.W. Dirsmith. (1991). The Management of Legitimacy and Politics in Public Sector Administration. Journal of Accounting and Public Policy 10(2), 135-156. http://dx.doi.org/10.1016/0278-4254(91)90009-9

Curran, L. (2003). Social Work and Fathers: Child Support and Fathering Programs. Social Work, 48(2), 219-227. http://dx.doi.org/10.1093/sw/48.2.219

DiMaggio, P., \& W. Powell. (1983). The Iron Cage Revisited: Institutional Isomorphism and Collective Rationality in Organizational Fields. American Sociological Review 48, 147-160. http://dx.doi.org/10.1016/S0742-3322(00)17011-1

Dunbar, A. (1996). The Impact of Personal Credits on the Progressivity of the Individual Income Tax. The Journal of the American Taxation Association, 18, 1-30.

Fleischman, G.M., S. Valentine, \& D.W. Finn. (2007). Ethical Reasoning and Equitable Relief. Behavioral Research in Accounting, 19(1), 107-132. http://dx.doi.org/10.2308/bria.2007.19.1.107

Fleischman, G.M., S. Valentine, S., \& D.W. Finn. (2009). Moral Intensity, Ethical Reasoning, and Equitable Relief Judgments. Research on Professional Responsibility and Ethics in Accounting (forthcoming). http://dx.doi.org/10.1108/S1574-0765(2010)0000014008

Flinn, C. J. (2000). Modes of Interaction Between Divorced Parents. International Economic Review 41(3), 545-579. http://dx.doi.org/10.1111/1468-2354.00076

Fogarty, T. J. (1992), Financial Accounting Standard Setting as an Institutionalized Action Field: Constraints, Opportunities and Dilemmas. Journal of Accounting and Public Policy 11, 331-355.

Folse, K.,\& H. Varela-Alvarez. (2002). Long-Run Economic Consequences of Child Support Enforcement for the Middle Class. Journal of Socio-Economics, 31(3), 273 - 286. http://dx.doi.org/10.1016/S1053-5357(02)00128-2

Garfinkel, I., \& P.K. Robins. (1994). The Relationship Between Child Support Enforcement Tools and Child Support Outcomes, in I. Garfinkel, McLanahan, S. \& Robins, P.K. (Eds.), Child Support and Child Well-Being, 133-171. Washington, D. C.: Urban Institute Press.

Horwitz, A.V. (1990). The Logic of Social Control. New York, NY: Plenum Press. http://dx.doi.org/10.1007/978-1-4899-2230-4

Hutchison, P.D., \& G.M. Fleischman. (2001). The Child Support Quandary: How Can Uncle Sam Help? Tax Notes, 92 , $563-565$.

Hutchison, P.D., G.M. Fleischman, \& S.B. Anders. (2007). Promoting Perceptions of Fairness: A Proposed Tax Incentive for Payers of Child Support. The CPA Journal, (June), 40-43.

Iyer, G., \& A. Seetharaman. (1997). Measuring the Statistical Significance of Differences in Tax Progressivity and Income Inequality. The Journal of the American Taxation Association, 19, 55-66.

Jagannathan, R. (2004). Children's Living Arrangements from a Social Policy Implementation Perspective. Children and Youth Services Review, 26(2), 121-141. http://dx.doi.org/10.1016/j.childyouth.2004.01.010

Kirchler, E.: (2007). The Economic Psychology of Tax Behaviour. Cambridge, England: Cambridge University Press. http://dx.doi.org/10.1017/CBO9780511628238

Knox, V. (1996). The Effects of Child Support Payments on Developmental Outcomes for Elementary School-Age Children. Journal of Human Resources, 31(4), 817-842. http://dx.doi.org/10.2307/146148

Kray, L. J., \& E.A. Lind. (2002). The Injustices of Others: Social Reports and the Integration of Others' Experiences in Organizational Justice Judgments. Organizational Behavior \& Human Decision Processes, 89(1), 906-925. http://dx.doi.org/10.1016/S0749-5978(02)00035-3

Lin, I. F. (2000). Perceived Fairness and Compliance with Child Support Obligations. Journal of Marriage and the Family, 62, 388-398.

Meyer, J. (1986). 'Institutional and organizational rationalization in the mental health system,' in The Organization of Mental Health Services (W.R. Scott \& Black, B.L., eds.). Beverly Hills, CA: Sage Publications, 15-29.

Meyer, J., \& B. Rowan. (1977). Institutional Organizations: Formal Structure as Myth and Ceremony. American Journal of Sociology, 83, 340-361. 
New York State Office of Temporary and Disability Assistance. (2007). New State Tax Credit Will Boost Refunds for Eligible Non-Custodial Parents, Accessed at: http://www.otda.state.ny.us/featured/default.htm\#feb05start

PEWORA. (1996). Personal Responsibility and Work Opportunity Reconciliation Act of 1996. 42 USC 1305-Public Law 104-193 (August 22, 1996).

Sasser, T. (1999). Child Support Myths and Truths: Exploring the Assumptions Underlying Florida's Statutory Guidelines. Florida Bar Journal, 73, 58-71.

Seetharaman, A. (1994). An Isolation of the Effects of Personal Deductions, Tax Credits, and the Tax Rate Schedule on U.S. Individual Income Tax Progressivity and Income Inequality. The Journal of the American Taxation Association, 16, 101-121.

Seetharaman, A., \& G. Iyer. (1995). A Comparison of Alternate Measures of Tax Progressivity: The Case of the Child and Dependent Care Credit. The Journal of the American Taxation Association, 17, 42-70.

Sorensen, E. (1997). A National Profile of Non-Custodial Fathers and their Ability to Pay Child Support. Journal of Marriage and the Family, 59, 785-797.

Sorensen, E., \& A. Halpern. (1999). Single Mothers and Their Child Support Receipt: How Well is Child Support Enforcement Doing? The Journal of Human Resources 39(1), 135-154. http://dx.doi.org/10.2307/3559008

Teachman, J. (1991). Who Pays? Receipt of Child Support in the United States. Journal of Marriage and the Family, 53(3), 759-772. http://dx.doi.org/10.2307/352749

Tebo, M. (2000). When Dad Won't Pay. ABA Journal, 86, 54-60.

United States Census Report. (2007). U.S. Census Bureau, Current Population Reports. Custodial Mothers and Fathers and Their Child Support: 2005 (August 2007).

United States Census Report. (2008). U.S. Census Bureau, Current Population Reports, Income, Poverty, and Health Insurance Coverage in the United States: 2007 (August 2008).

United States Congress, Joint Committee. (1981). General Explanation of the Economic Recovery Tax Act of 1981 [H.R. 4242]. $97^{\text {th }}$ Congress, $1^{\text {st }}$ Session.

van den Bos, K. (2002). Assimilation and Contrast in Organizational Justice: The Role of Primed Mindsets in the Psychology of the Fair Process Effect. Organizational Behavior and Human Decision Processes, 89, 866-880.

Weiss, Y., \& R.Willis. (1985). Children as Collective Goods and Divorce Settlements. Journal of Labor Economics 3(3), 268-292. http://dx.doi.org/10.1086/298056

Young, J., S. Nutter, \& P. Wilkie. (1999). A Re-Examination of the Effects of Personal Deductions, Tax Credits and the Tax Rate Schedule on Income Progressivity and Income Inequality. The Journal of the American Taxation Association, 21, 32-44.

\section{Notes}

Note 1. Because single parents are 80 to 85 percent of the time mothers according to Tebo (2000) and Lin (2000), the authors use the personal pronoun "she" for the resident (custodial) parent and "he" for the non-custodial parent. 